\title{
Ventilatory Response to Carbon Dioxide Output in Subjects With Congestive Heart Failure and in Patients with COPD With Comparable Exercise Capacity
}

\author{
Elisabetta Teopompi PhD, Panagiota Tzani PhD, Marina Aiello PhD, Sara Ramponi MD, \\ Dina Visca MD, Maria Rosaria Gioia MD, Emilio Marangio MD, \\ Walter Serra MD, and Alfredo Chetta MD
}

\begin{abstract}
BACKGROUND: Patients with congestive heart failure or COPD may share an increased response in minute ventilation $\left(\dot{\mathrm{V}}_{\mathrm{E}}\right)$ to carbon dioxide output $\left(\dot{\mathrm{V}}_{\mathrm{CO}_{2}}\right)$ during exercise. The goal of this study was to ascertain whether the $\dot{\mathrm{V}}_{\mathrm{E}} / \dot{\mathrm{V}}_{\mathrm{CO}_{2}}$ slope and $\dot{\mathrm{V}}_{\mathrm{E}} / \dot{\mathrm{V}}_{\mathrm{CO}_{2}}$ intercept can discriminate between subjects with congestive heart failure and those with COPD at equal peak oxygen uptake $\left(\dot{\mathrm{V}}_{\mathrm{O}_{2}}\right)$. METHODS: We studied 46 subjects with congestive heart failure (mean age $61 \pm 9 \mathrm{y}$ ) and 46 subjects with COPD (mean age $64 \pm 8$ y) who performed a cardiopulmonary exercise test. RESULTS: The $\dot{\mathrm{V}}_{\mathbf{E}} / \dot{\mathrm{V}}_{\mathbf{C O}}$ slope was significantly higher in subjects with congestive heart failure compared with those with COPD $(39.5 \pm 9.5$ vs $31.8 \pm 7.4, P<.01)$ at peak $\dot{\mathrm{V}}_{\mathrm{O}_{2}}<16 \mathrm{~mL} / \mathrm{kg} / \mathrm{min}$, but not $\geq 16 \mathrm{~mL} / \mathrm{kg} / \mathrm{min}(28.3 \pm 5.3 \mathrm{vs} 28.9 \pm 6.6)$. The $\dot{\mathrm{V}}_{\mathrm{E}} / \dot{\mathrm{V}}_{\mathrm{CO}_{2}}$ intercept was significantly higher in both subgroups of subjects with COPD compared with the corresponding values in the subjects with congestive heart failure $(3.60 \pm 1.7 \mathrm{vs}-0.16 \pm 1.7 \mathrm{~L} / \mathrm{min}, P<.01 ; 3.63 \pm 2.7 \mathrm{vs} 0.87 \pm 1.5 \mathrm{~L} / \mathrm{min}$, $P<.01)$. According to receiver operating characteristic curve analysis, when all subjects with peak $\dot{\mathrm{V}}_{\mathrm{O}}<16 \mathrm{~mL} / \mathrm{kg} / \mathrm{min}$ were considered, subjects with COPD had a higher likelihood to have the $\dot{\mathrm{V}}_{\mathrm{E}} / \dot{\mathrm{V}}_{\mathrm{CO}_{2}}$ intercept $>2.14 \mathrm{~L} / \mathrm{min}\left(0.92\right.$ sensitivity, 0.96 specificity). Regardless of peak $\dot{\mathrm{V}}_{\mathrm{O}_{2}}$, the end-tidal pressure of $\mathrm{CO}_{2}\left(\mathrm{P}_{\mathrm{ETCO}_{2}}\right)$ at peak exercise was not different in subjects with congestive heart failure $(P=.42)$ and was significantly higher in subjects with COPD $(P<.01)$ compared with the corresponding unloaded $P_{\mathrm{ETCO}_{2}}$ CONCLUSIONS: The ventilatory response to $\dot{V}_{\mathrm{CO}_{2}}$ during exercise was significantly different between subjects with congestive heart failure and those with COPD in terms of the $\dot{\mathrm{V}}_{\mathrm{E}} / \dot{\mathrm{V}}_{\mathrm{CO}_{2}}$ slope with moderate-to-severe reduction in exercise capacity and in terms of the $\dot{\mathbf{V}}_{\mathbf{E}} / \dot{\mathbf{V}}_{\mathbf{C O}_{2}}$ intercept regardless of exercise capacity. Key words: congestive heart failure; COPD; exercise; ventilatory response. [Respir Care 2014;59(7):1034-1041. (C) 2014 Daedalus Enterprises]
\end{abstract}

Introduction

Poor exercise tolerance, demonstrated by a reduction in peak oxygen uptake (peak $\dot{\mathrm{V}}_{\mathrm{O}_{2}}$ ) during a rapidly incremental cardiopulmonary exercise test (CPET), may occur in

\footnotetext{
The authors are affiliated with the Respiratory Disease and Lung Function Unit, with the exception of Dr Serra, who is affiliated with the Cardiac Unit, University Hospital, Parma, Italy.
}

The authors have disclosed no conflicts of interest.

DOI: $10.4187 /$ respcare.02629 chronic cardiopulmonary disabling conditions, such as congestive heart failure and COPD.

While performing a CPET, subjects with congestive heart failure $^{1,2}$ and $\mathrm{COPD}^{3,4}$ may share a different from normal ventilatory response to carbon dioxide output $\left(\dot{\mathrm{V}}_{\mathrm{CO}_{2}}\right)$. The mechanisms underlying the control of exercise hyperpnoea are complex and still under investigation both in

See the Related Editorial on Page 1157

healthy subjects ${ }^{5}$ and in cardiopulmonary patients. ${ }^{6,7} \mathrm{Re}-$ gardless of rate, the minute ventilation $\left(\dot{V}_{\mathrm{E}}\right)$ for a given metabolic rate $\left(\dot{\mathrm{V}}_{\mathrm{E}} / \dot{\mathrm{V}}_{\mathrm{CO}_{2}}\right)$, also known as ventilatory equiv- 
alent for $\mathrm{CO}_{2},{ }^{8}$ may be increased both in congestive heart failure and COPD during exercise. Notably, the slope of the $\dot{\mathrm{V}}_{\mathrm{E}} / \dot{\mathrm{V}}_{\mathrm{CO}_{2}}$ linear relationship is considered as the strongest prognostic marker (including peak $\dot{\mathrm{V}}_{\mathrm{O}_{2}}$ ) in patients with congestive heart failure, regardless of the etiology of cardiomyopathy, ${ }^{9}$ and was found to be a significant postsurgical prognostic marker in patients with COPD undergoing lung resection. ${ }^{10}$ Moreover, it has been recently recognized that even the intercept of the $\dot{\mathrm{V}}_{\mathrm{E}} / \dot{\mathrm{V}}_{\mathrm{CO}_{2}}$ relationship may be relevant in fully understanding ventilatory control mechanisms in health ${ }^{7}$ and in disease. 6,7

Up to now, no study has aimed to compare the ventilatory response to $\dot{\mathrm{V}}_{\mathrm{CO}_{2}}$ in subjects with congestive heart failure and COPD with comparable exercise capacity or to assess the possible discriminating value of $\dot{\mathrm{V}}_{\mathrm{E}} / \dot{\mathrm{V}}_{\mathrm{CO}_{2}}$ measurement in these patients. The aim of the present study was to measure $\dot{\mathrm{V}}_{\mathrm{E}} / \dot{\mathrm{V}}_{\mathrm{CO}_{2}}$ in terms of both slope and intercept in a cohort of subjects with congestive heart failure and COPD and to ascertain whether the $\dot{\mathrm{V}}_{\mathrm{E}} / \dot{\mathrm{V}}_{\mathrm{CO}_{2}}$ slope and intercept may discriminate between these patients at equal peak $\dot{\mathrm{V}}_{\mathrm{O}_{2}}$.

\section{Methods}

\section{Subjects}

Over a 6-month period (from November 2012 to April 2013), we consecutively enrolled subjects affected by congestive heart failure due to ischemic or idiopathic dilated cardiomyopathy referred for CPET, as part of a comprehensive heart failure evaluation, and subjects with COPD, who were admitted to a pulmonary rehabilitation program.

All subjects with congestive heart failure had a history of at least one confirmed clinical episode of heart failure and an echocardiographic left-ventricular ejection fraction of $<50 \%$. Subjects with congestive heart failure and uncontrolled atrial fibrillation or history of sustained ventricular tachycardia, recent syncope, or myocardial infarct were excluded. ${ }^{11}$ COPD was diagnosed according to the Global Initiative for Chronic Obstructive Lung Disease criteria, ${ }^{12}$ and subjects with moderate-to-severe air-flow obstruction (ie, $\mathrm{FEV}_{1} /$ vital capacity [VC]) $<0.70$ and $\mathrm{FEV}_{1}<80 \%$ of predicted) were included.

For all subjects, eligibility criteria were: (1) age range of $40-75 \mathrm{y}$, (2) body mass index $\leq 30 \mathrm{~kg} / \mathrm{m}^{2}$, (3) stable clinical condition for at least 8 weeks, (4) absence of any comorbidity affecting exercise performance (anemia, neuromuscular disorders, or malignancies), (5) ability to perform a CPET with a peak of respiratory exchange ratio of $\geq 1.05$ to exclude poor motivation, ${ }^{11}$ and (6) CPET stopped for muscle fatigue and/or dyspnea.

All procedures and their risks were explained to the subjects, who gave their written informed consent to enter the study, which was conducted according to the Decla-

\section{QUICK LOOK}

\section{Current knowledge}

The ventilatory response to carbon dioxide production $\left(\dot{\mathrm{V}}_{\mathrm{E}} / \dot{\mathrm{V}}_{\mathrm{CO}_{2}}\right)$ is a function of alveolar ventilation and ventilation/perfusion matching. Alterations in the response to an increased $\dot{V}_{\mathrm{CO}_{2}}$ can be diagnostic for cardiac and respiratory disease.

\section{What this paper contributes to our knowledge}

The ventilatory response to $\dot{\mathrm{V}}_{\mathrm{CO}_{2}}$ during progressive exercise was significantly different between subjects with congestive heart failure and those with COPD. The slope and intercept of the $\dot{\mathrm{V}}_{\mathrm{E}} / \dot{\mathrm{V}}_{\mathrm{CO}_{2}}$ was altered, and this finding can be used to discriminate between cardiac and pulmonary disease.

ration of Helsinki. The protocol was approved by the ethics committee of the University Hospital of Parma. All participants' data were analyzed and reported anonymously. No extramural funding was used to support the study.

\section{Measurements}

Pulmonary Function Testing. Pulmonary function tests were performed according to international recommendations. ${ }^{13,14}$ A flow-sensing spirometer and a body plethysmograph connected to a computer for data analysis (Vmax 22 and 6200, SensorMedics, Yorba Linda, California) were used for these measurements. Total lung capacity (TLC), $\mathrm{VC}, \mathrm{FEV}_{1}$, and $\mathrm{FEV}_{1} / \mathrm{VC}$ were recorded. TLC, VC, and $\mathrm{FEV}_{1}$ were expressed as a percentage of the predicted values. ${ }^{15}$

Cardiopulmonary Exercise Test. CPET was performed according to a standardized procedure. ${ }^{11}$ Briefly, the exercise protocol started with an initial 3 min of rest, followed by unloaded cycling for $3 \mathrm{~min}$ with a subsequent increment of 5-15 watts each minute, depending on the anthropometric data and the degree of individual functional impairment, with the aim to perform a total exercise time ranging 8 to $12 \mathrm{~min}$. Subjects were asked to maintain a pedaling frequency of $60 \mathrm{rpm}$ as indicated by a digital display placed on the monitor of the cycle ergometer (Corival PB, Lode BV, Groningen, The Netherlands). Breathby-breath $\dot{\mathrm{V}}_{\mathrm{O}_{2}}(\mathrm{~L} / \mathrm{min}), \dot{\mathrm{V}}_{\mathrm{CO}_{2}}(\mathrm{~L} / \mathrm{min})$, and $\dot{\mathrm{V}}_{\mathrm{E}}(\mathrm{L} / \mathrm{min})$ were recorded during the test (CPX/D, Medical Graphics, Minneapolis, Minnesota). Subjects were continuously monitored by a 12-lead electrocardiogram (CardioPerfect, Welch Allyn, Delft, The Netherlands) and a pulse oximeter (model 8600, Nonin, Plymouth, Minnesota). Blood pressure 
$(\mathrm{mm} \mathrm{Hg})$ was measured at 2-min intervals. Stopping criteria consisted of symptoms such as unsustainable dyspnea or leg fatigue, chest pain, electrocardiogram significant ST-segment depression, a drop in systolic blood pressure, or arterial oxygen saturation $\leq 84 \%$.

Peak work load and peak $\dot{\mathrm{V}}_{\mathrm{O}_{2}}$ were recorded as the mean value of watts and $\dot{\mathrm{V}}_{\mathrm{O}_{2}}(\mathrm{~mL} / \mathrm{kg} / \mathrm{min})$ during the last $20 \mathrm{~s}$ of the test. Anaerobic threshold was noninvasively determined by both V-slope and ventilatory equivalents methods (dual-method approach) and was expressed in $\mathrm{mL} / \mathrm{kg} / \mathrm{min}$ of $\dot{\mathrm{V}}_{\mathrm{O}_{2}}{ }^{11}$ The ventilatory response during exercise was expressed as a linear regression function by plotting $\dot{\mathrm{V}}_{\mathrm{E}}$ against $\dot{\mathrm{V}}_{\mathrm{CO}_{2}}$ obtained every $10 \mathrm{~s}$, excluding data above the ventilatory compensation point, ${ }^{11}$ and by measuring the slope $\left(\dot{\mathrm{V}}_{\mathrm{E}} / \dot{\mathrm{V}}_{\mathrm{CO}_{2}}\right.$ slope $)$ and y intercept $\left(\dot{\mathrm{V}}_{\mathrm{E}} / \dot{\mathrm{V}}_{\mathrm{CO}_{2}}\right.$ intercept $)$. The end-tidal pressure of $\mathrm{CO}_{2}\left(\mathrm{P}_{\mathrm{ETCO}_{2}}\right.$, $\mathrm{mm} \mathrm{Hg}$ ) was recorded as the mean value of $\mathrm{P}_{\mathrm{ETCO}_{2}}$ during the 3-min rest period (unloaded $\mathrm{P}_{\mathrm{ETCO}_{2}}$ ), during the last $20 \mathrm{~s}$ of the test (peak $\mathrm{P}_{\mathrm{ETCO}_{2}}$ ), and as the difference between peak and unloaded $\mathrm{P}_{\text {ETCO }}$.

The cardiovascular response to exercise was expressed as oxygen pulse and double product. The oxygen pulse ( $\mathrm{mL}$ of $\mathrm{O}_{2}$ consumed/heartbeat) was calculated by dividing the instantaneous oxygen uptake by heart rate ${ }^{11}$ and was recorded at the peak of exercise. The double product at rest and at maximum exercise was calculated by the product of systolic blood pressure and heart rate and expressed as double-product reserve (double product at maximum exercise minus double product at rest, $\mathrm{mm} \mathrm{Hg} /$ beats/ $\min ) .{ }^{16}$

Functional Status, Dyspnea, and Muscle Fatigue. The functional status of the subjects with congestive heart failure was categorized according to the New York Heart Association functional classification system (classes I-IV). ${ }^{17}$ Briefly, the New York Heart Association classification places patients with cardiac disease in one of 4 categories based on physical activity limitation: class I, patients without limitation of physical activity (ie, ordinary physical activity does not cause undue fatigue, palpitation, dyspnea, or anginal pain); class II, patients with slight limitation of physical activity (ie, they are comfortable at rest, but ordinary physical activity results in fatigue, palpitation, dyspnea, or anginal pain); class III, patients with marked limitation of physical activity (ie, they are comfortable at rest, but less than ordinary activity causes fatigue, palpitation, dyspnea, or anginal pain); and class IV, patients with inability to carry on any physical activity without discomfort (symptoms of heart failure or the anginal syndrome may be present even at rest, and if any physical activity is undertaken, discomfort increases).

In subjects with COPD, the activity of daily living (ADL)related dyspnea was evaluated using the Italian version of the 5-point Medical Research Council dyspnea scale mod- ified by the American Thoracic Society. ${ }^{18}$ In all subjects, dyspnea and muscle fatigue induced by CPET were measured at the end of incremental exercise by a visual analog scale (dyspnea and fatigue, respectively; $\mathrm{mm}$ ) as described previously. ${ }^{19}$ Briefly, the visual analog scale consisted of a horizontal line with the word "none" placed at the left end of the scale and the words "very severe" placed at the right end of the scale. The visual analog scale was scored from 0 to 100, but the subjects were unaware of the numbers.

Echocardiography. In subjects with congestive heart failure, a complete Doppler echocardiographic evaluation was performed within a 3-week period before pulmonary function testing and CPET. Echocardiograms were recorded using a commercially available machine (System five, GE Healthcare, Madison, Wisconsin) equipped with 2.5- and 3.5-MHz electronic transducers and harmonic imaging. Left-ventricular chamber dimensions were measured according to the recommendations of the American Society of Echocardiography. ${ }^{20}$ Left-ventricular systolic function was evaluated, and left-ventricular ejection fraction (\%) was recorded according to the single-plane area-length method.

Body Composition. Body height and weight were measured anthropometrically in all subjects. Body composition was assessed by a bioelectrical impedance analysis method that is based on the conductance of an electrical sinusoidal alternating current through body fluids. Bioelectrical impedance analysis measures the impedance or resistance to the signal as it travels through the water that is found in muscle and fat. Foot-to-foot bioelectrical impedance analysis was performed using an SC-331S body composition analyzer (Tanita, Tokyo, Japan). Subjects were measured while standing in bare feet on analyzer footpads. The algorithms used to estimate lean body mass from impedance are those given by Segal et al. ${ }^{21}$ The fat-free mass was standardized for height similar to body mass index: fat-free mass $/$ height $^{2}\left(\mathrm{~kg} / \mathrm{m}^{2}\right)$.

\section{Statistical Analysis}

Data are reported as mean \pm SD unless specified otherwise. Due to the explorative nature of the study, no formal sample size calculation was performed. The distribution of variables was assessed by the KolmogorovSmirnov goodness-of-fit test. Relationships between variables were assessed by Pearson correlation coefficient $(r)$ and linear regression analysis. Comparisons between variables were determined by unpaired $t$ test and chi-square test when appropriate.

According to peak $\dot{\mathrm{V}}_{\mathrm{O}_{2}}$, the population sample was divided into subjects with moderate-to-severe reduction in 
Table 1. Exercise Characteristics of Subjects with Congestive Heart Failure and COPD Categorized According to Peak $\dot{\mathrm{V}}_{\mathrm{O}_{2}}$

\begin{tabular}{|c|c|c|c|c|c|c|}
\hline & \multicolumn{3}{|c|}{ Peak $\dot{\mathrm{V}}_{\mathrm{O}_{2}}<16 \mathrm{~mL} / \mathrm{kg} / \mathrm{min}$} & \multicolumn{3}{|c|}{ Peak $\dot{\mathrm{V}}_{\mathrm{O}_{2}} \geq 16 \mathrm{~mL} / \mathrm{kg} / \mathrm{min}$} \\
\hline & $\begin{array}{l}\text { Congestive } \\
\text { Heart Failure } \\
(n=23)\end{array}$ & $\begin{array}{c}\text { COPD } \\
(n=24)\end{array}$ & $P$ & $\begin{array}{l}\text { Congestive } \\
\text { Heart Failure } \\
(n=23)\end{array}$ & $\begin{array}{l}\text { COPD } \\
(n=22)\end{array}$ & $P$ \\
\hline Age, mean \pm SD $(y)$ & $63 \pm 8$ & $67 \pm 6$ & .061 & $59 \pm 10$ & $61 \pm 8$ & .40 \\
\hline Gender (male/female) & $14 / 9$ & $14 / 10$ & .86 & $19 / 4$ & $20 / 2$ & .41 \\
\hline Fat-free mass index, mean $\pm \mathrm{SD}\left(\mathrm{kg} / \mathrm{m}^{2}\right)$ & $17.9 \pm 2.0$ & $16.9 \pm 1.7$ & .11 & $19.2 \pm 1.4$ & $18.6 \pm 1.9$ & .29 \\
\hline Peak $\dot{\mathrm{V}}_{\mathrm{O}_{2}}$, mean $\pm \mathrm{SD}(\mathrm{mL} / \mathrm{kg} / \mathrm{min})$ & $12.1 \pm 2.1$ & $12.9 \pm 1.9$ & .14 & $20.0 \pm 4.1$ & $19.8 \pm 3.3$ & .85 \\
\hline Anaerobic threshold, mean $\pm \mathrm{SD}\left(\mathrm{mL} / \mathrm{kg} / \mathrm{min}\right.$ of $\left.\dot{\mathrm{V}}_{\mathrm{O}_{2}}\right)$ & $8.6 \pm 1.5$ & $9.8 \pm 1.7$ & .03 & $13.4 \pm 4.2$ & $13.7 \pm 3.2$ & .83 \\
\hline Work load, mean $\pm \mathrm{SD}$ (watts) & $63.9 \pm 18$ & $67.5 \pm 21$ & .53 & $119.6 \pm 38$ & $111 \pm 39$ & .48 \\
\hline$\dot{\mathrm{V}}_{\mathrm{E}}$, mean $\pm \mathrm{SD}(\mathrm{L} / \mathrm{min})$ & $38.9 \pm 11$ & $36.8 \pm 12$ & .54 & $53.9 \pm 14$ & $50.2 \pm 14$ & .38 \\
\hline$\dot{\mathrm{V}}_{\mathrm{E}} / \dot{\mathrm{V}}_{\mathrm{CO}_{2}}$ slope, mean $\pm \mathrm{SD}$ & $39.5 \pm 9.5$ & $31.8 \pm 7.4$ & .004 & $28.3 \pm 5.3$ & $28.9 \pm 6.6$ & .71 \\
\hline$\dot{\mathrm{V}}_{\mathrm{E}} / \dot{\mathrm{V}}_{\mathrm{CO}_{2}}$ intercept, mean $\pm \mathrm{SD}(\mathrm{L} / \mathrm{min})$ & $-0.16 \pm 1.7$ & $3.60 \pm 1.7$ & .001 & $0.87 \pm 1.5$ & $3.63 \pm 2.7$ & .001 \\
\hline Unloaded $\mathrm{P}_{\mathrm{ETCO}_{2}}$, mean $\pm \mathrm{SD}(\mathrm{mm} \mathrm{Hg})$ & $32.7 \pm 4.7$ & $31.7 \pm 5.4$ & .53 & $38.9 \pm 5.2$ & $33.8 \pm 7.2$ & .009 \\
\hline Peak $\mathrm{P}_{\mathrm{ETCO}_{2}}$, mean $\pm \mathrm{SD}(\mathrm{mm} \mathrm{Hg})$ & $31.8 \pm 5.8$ & $38.2 \pm 7.02$ & .002 & $38.8 \pm 6.7$ & $41.4 \pm 9.1$ & .29 \\
\hline Peak $\mathrm{P}_{\mathrm{ETCO}_{2}}$ - unloaded $\mathrm{P}_{\mathrm{ETCO}_{2}}$, mean $\pm \mathrm{SD}(\mathrm{mm} \mathrm{Hg})$ & $-0.83 \pm 2.9$ & $6.46 \pm 4.35$ & .002 & $-0.13 \pm 4.9$ & $7.54 \pm 5.9$ & .001 \\
\hline Oxygen pulse, mean $\pm \mathrm{SD}\left(\mathrm{mL}\right.$ of $\mathrm{O}_{2}$ consumed/heartbeat $)$ & $9.53 \pm 2.7$ & $8.46 \pm 2.1$ & .13 & $12.7 \pm 2.9$ & $11.9 \pm 2.7$ & .39 \\
\hline Double-product reserve, mean $\pm \mathrm{SD}(\mathrm{mm} \mathrm{Hg} / \mathrm{beats} / \mathrm{min})$ & $6,017 \pm 3,379$ & $9,032 \pm 4,056$ & .008 & $10,460 \pm 4,622$ & $13,065 \pm 3,731$ & .044 \\
\hline \multicolumn{7}{|l|}{ Visual analog scale } \\
\hline Dyspnea $(0-100)$ & $80(80-90)$ & $90(72-100)$ & .56 & $80(60-90)$ & $80(80-90)$ & .30 \\
\hline Fatigue $(0-100)$ & $90(80-100)$ & $80(62-90)$ & .047 & $90(80-100)$ & $85(70-90)$ & .25 \\
\hline $\begin{array}{l}\dot{\mathrm{V}}_{\mathrm{O}_{2}}=\text { oxygen uptake } \\
\mathrm{V}_{\mathrm{E}}=\text { minute ventilation } \\
\mathrm{V}_{\mathrm{CO}_{2}}=\text { carbon dioxide output } \\
\mathrm{P}_{\mathrm{ETCO}_{2}}=\text { end-tidal pressure of } \mathrm{CO}_{2} \\
\mathrm{~V}_{\mathrm{E}} / \mathrm{V}_{\mathrm{CO}_{2}}=\text { ventilatory equivalent for } \mathrm{CO}_{2}\end{array}$ & & & & & & \\
\hline
\end{tabular}

exercise capacity (peak $\dot{\mathrm{V}}_{\mathrm{O}_{2}}<16 \mathrm{~mL} / \mathrm{kg} / \mathrm{min}$ ) and subjects with mild reduction in exercise capacity (peak $\left.\dot{\mathrm{V}}_{\mathrm{O}_{2}} \geq 16 \mathrm{~mL} / \mathrm{kg} / \mathrm{min}\right) .^{22}$

The receiver operating characteristic curve method ${ }^{23}$ was used to plot the true positive rate (sensitivity) in function of the false-positive rate (100 specificity) for different cutoff points of the $\dot{\mathrm{V}}_{\mathrm{E}} / \dot{\mathrm{V}}_{\mathrm{CO}_{2}}$ slope and intercept to discriminate between subjects with congestive heart failure and those with COPD . $P<.05$ was taken as significant.

\section{Results}

Of the 130 consecutive subjects who agreed to participate in the study, 18 subjects were excluded because their body mass index was $>30 \mathrm{~kg} / \mathrm{m}^{2}, 7$ subjects were excluded because they were $>75$ y old, and 13 subjects were excluded because of comorbidities. Ninety-two stable subjects (46 with congestive heart failure and 46 with COPD), 42-75 y old, were included in the study. Subjects with congestive heart failure did not differ in gender (33/13 vs $34 / 12$ male/female ratio, $P=.82$ ) and tended to be younger (61 \pm 9 vs $64 \pm 8 \mathrm{y}, P=.068)$ compared with subjects with COPD.

In subjects with congestive heart failure, New York Heart Association classes ranged from I to IV (median of
II), and their left-ventricular ejection fraction was $32 \pm 9 \%$, ranging from 15 to $48 \%$. At the moment of the study, subjects with congestive heart failure were receiving regular therapy with $\beta$ blockers (98\%), diuretics (83\%), and angiotensin-converting enzyme inhibitors (76\%), whereas subjects with COPD were receiving inhaled steroids (65\%), long-acting $\beta_{2}$ agonists (61\%), and tiotropium (43\%). All subjects with COPD were ex-smokers, and among them, a wide range of ADL or activity of daily living-related dyspnea (Medical Research Council dyspnea scale of 0-4) was found. As expected, subjects with congestive heart failure significantly differed from subjects with COPD in terms of TLC ( $94 \pm 16 \%$ vs $118 \pm 25 \%), \mathrm{FEV}_{1}(91 \pm 17 \%$ vs $52 \pm 16 \%)$ and $\mathrm{FEV}_{1} / \mathrm{VC}(0.75 \pm 0.06$ vs $0.48 \pm 0.12$, $P<.001$ for all comparisons).

All subjects completed the exercise test without any complication. Peak $\dot{\mathrm{V}}_{\mathrm{O}_{2}}$ ranged from 7.2 to $31.0 \mathrm{~mL} / \mathrm{kg} /$ min and from 7.7 to $30.2 \mathrm{~mL} / \mathrm{kg} / \mathrm{min}$ in subjects with congestive heart failure and COPD, respectively. Twentythree of 46 subjects with congestive heart failure and 24 of 46 subjects with COPD had peak $\dot{\mathrm{V}}_{\mathrm{O}_{2}}<16 \mathrm{~mL} / \mathrm{kg} / \mathrm{min}$, whereas 23 subjects with congestive heart failure and 22 subjects with COPD had peak $\dot{\mathrm{V}}_{\mathrm{O}_{2}} \geq 16 \mathrm{~mL} / \mathrm{kg} / \mathrm{min}$. The two subgroups of subjects categorized according to peak $\dot{\mathrm{V}}_{\mathrm{O}_{2}}$ did not significantly differ in terms of age, gender, and 
A

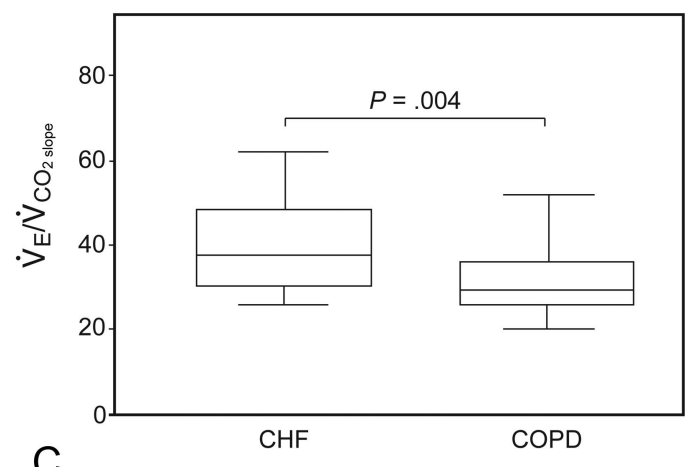

C

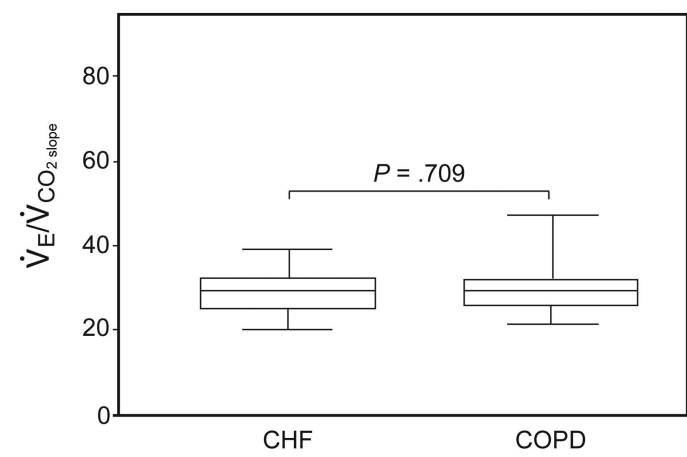

B

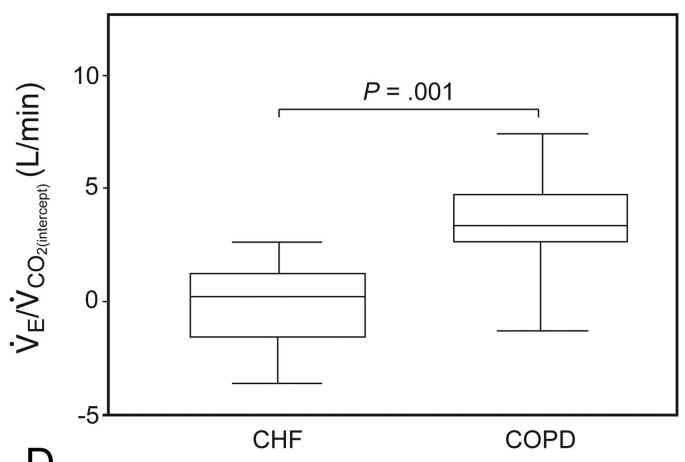

D

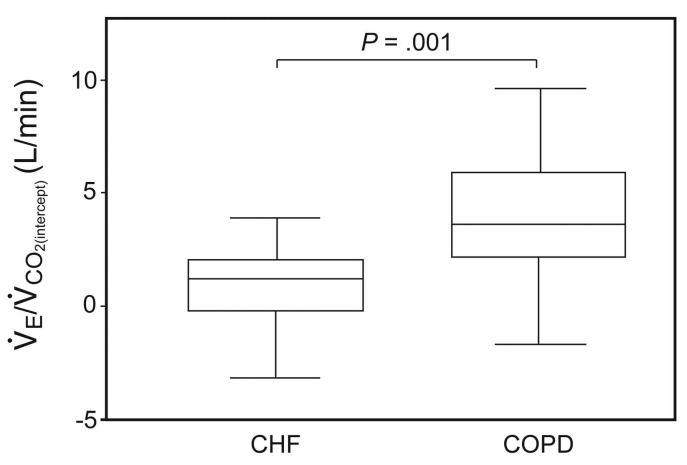

Fig. 1. Data are expressed as mean $\pm \mathrm{SD}$ and ranges for 46 subjects with congestive heart failure (CHF) patients and 46 subjects with COPD. A: minute ventilation $\left(\dot{V}_{\mathrm{E}}\right) /$ carbon dioxide output $\left(\dot{\mathrm{V}}_{\mathrm{CO}_{2}}\right)$ slope with peak $\dot{\mathrm{V}}_{\mathrm{O}_{2}}<16 \mathrm{~mL} / \mathrm{kg} / \mathrm{min}$. B: $\dot{\mathrm{V}}_{\mathrm{E}} / \dot{\mathrm{V}}_{\mathrm{CO}}$ intercept with peak $\dot{\mathrm{V}}_{\mathrm{O}_{2}}<16$ $\mathrm{mL} / \mathrm{kg} / \mathrm{min}$. C: $\dot{\mathrm{V}}_{\mathrm{E}} / \dot{\mathrm{V}}_{\mathrm{CO}_{2}}$ slope with peak $\dot{\mathrm{V}}_{\mathrm{O}_{2}} \geq 16 \mathrm{~mL} / \mathrm{kg} / \mathrm{min}$. D: $\dot{\mathrm{V}}_{\mathrm{E}} / \dot{\mathrm{V}}_{\mathrm{CO}_{2}}$ intercept with peak $\dot{\mathrm{V}}_{\mathrm{O}_{2}} \geq 16 \mathrm{~mL} / \mathrm{kg} / \mathrm{min}$.

fat-free index $(P>.05$ for all comparisons) (Table 1). COPD subjects with lower peak $\dot{\mathrm{V}}_{\mathrm{O}_{2}}$ tended to show worse resting lung function without reaching statistical significance (TLC: $124 \pm 25 \%$ vs $113 \pm 24 \%, P=.15 ; \mathrm{FEV}_{1}$ : $49 \pm 14 \%$ vs $54 \pm 15 \%, P=.18 ; \mathrm{FEV}_{1} / \mathrm{VC}: 0.45 \pm 0.11$ vs $0.52 \pm 0.12, P=.056$ ). No significant difference was found in resting lung function between congestive heart failure subjects with peak $\dot{\mathrm{V}}_{\mathrm{O}_{2}}<16 \mathrm{~mL} / \mathrm{kg} / \mathrm{min}$ and those with peak $\dot{\mathrm{V}}_{\mathrm{O}_{2}} \geq 16 \mathrm{~mL} / \mathrm{kg} / \mathrm{min}$ (TLC: $93 \pm 19 \%$ vs $96 \pm 13 \%, P=.55 ; \mathrm{FEV}_{1}: 88 \pm 20 \%$ vs $94 \pm 11 \%$, $P=.19 ; \mathrm{FEV}_{1} / \mathrm{VC}: 0.75 \pm 0.05$ vs $0.75 \pm 0.07, P=.94$ ). In the group of subjects with peak $\dot{\mathrm{V}}_{\mathrm{O}_{2}}<16 \mathrm{~mL} / \mathrm{kg} / \mathrm{min}$, the anaerobic threshold $\left(\mathrm{mL} / \mathrm{kg} / \mathrm{min}\right.$ of $\mathrm{V}_{\mathrm{O}_{2}}$ ) was significantly lower in subjects with congestive heart failure than in those with COPD $(P=.03)$ (see Table 1).

The $\dot{\mathrm{V}}_{\mathrm{E}} / \dot{\mathrm{V}}_{\mathrm{CO}_{2}}$ slope was significantly higher in congestive heart failure subjects with peak $\dot{\mathrm{V}}_{\mathrm{O}_{2}}<16 \mathrm{~mL} / \mathrm{kg} / \mathrm{min}$ compared with the corresponding values in the COPD group, but were not different between congestive heart failure and COPD subjects with peak $\dot{\mathrm{V}}_{\mathrm{O}_{2}} \geq 16 \mathrm{~mL} / \mathrm{kg} / \mathrm{min}$ (see Table 1 and Fig. 1). On the other hand, the $\dot{\mathrm{V}}_{\mathrm{E}} / \dot{\mathrm{V}}_{\mathrm{CO}_{2}}$ intercept was significantly higher in all subjects with COPD (peak $\dot{\mathrm{V}}_{\mathrm{O}_{2}}<16 \mathrm{~mL} / \mathrm{kg} / \mathrm{min}$ and peak $\dot{\mathrm{V}}_{\mathrm{O}_{2}} \geq 16 \mathrm{~mL} / \mathrm{kg} / \mathrm{min}$ ) compared with the corresponding values in subjects with congestive heart failure (see Table 1 and Fig. 1). Furthermore, the $\dot{\mathrm{V}}_{\mathrm{E}} / \dot{\mathrm{V}}_{\mathrm{CO}_{2}}$ intercept was positive in 43 of 46 sub- jects with COPD and in 28 of 46 subjects with congestive heart failure.

To discriminate between subjects with congestive heart failure and those with COPD categorized according to peak $\dot{\mathrm{O}}_{\mathrm{O}_{2}}$, the receiver operating characteristic curve analysis showed that the $\dot{\mathrm{V}}_{\mathrm{E}} / \dot{\mathrm{V}}_{\mathrm{CO}_{2}}$ slope had a significant cutoff point only for subjects with peak $\dot{\mathrm{V}}_{\mathrm{O}_{2}}<16 \mathrm{~mL} / \mathrm{kg} / \mathrm{min}$, whereas the $\dot{\mathrm{V}}_{\mathrm{E}} / \dot{\mathrm{V}}_{\mathrm{CO}_{2}}$ intercept had significant cutoff points for both subgroups of subjects and showed higher values in sensitivity and specificity compared with the corresponding values of the $\dot{\mathrm{V}}_{\mathrm{E}} / \dot{\mathrm{V}}_{\mathrm{CO}_{2}}$ slope (Table 2).

Peak $\mathrm{P}_{\mathrm{ETCO}_{2}}$ was not different compared with the corresponding unloaded $\mathrm{P}_{\mathrm{ETCO}}$ in subjects with congestive heart failure $(P=.42)$, but was significantly higher in subjects with COPD $(P<.001)$. The difference between peak and unloaded $\mathrm{P}_{\mathrm{ETCO}}$ was also significantly different between subjects with congestive heart failure and those with COPD both with peak $\dot{\mathrm{V}}_{\mathrm{O}_{2}}<16 \mathrm{~mL} / \mathrm{kg} / \mathrm{min}$ and peak $\dot{\mathrm{V}}_{\mathrm{O}_{2}} \geq 16 \mathrm{~mL} / \mathrm{kg} / \mathrm{min}$ (see Table 1 ).

Subjects with congestive heart failure differed from those with COPD in double-product reserve, but not in oxygen pulse, at both mild and moderate-to-severe reduction in functional capacity (see Table 1). With respect to exerciseinduced symptoms, subjects with congestive heart failure experienced more leg fatigue than subjects with COPD 
Table 2. Receiver Operating Characteristic Curve Analysis of the $\dot{\mathrm{V}}_{\mathrm{E}} / \dot{\mathrm{V}}_{\mathrm{CO}_{2}}$ Slope and Intercept to Discriminate Between Subjects with Congestive Heart Failure and Those With COPD Categorized According to Peak $\dot{\mathrm{V}}_{\mathrm{O}_{2}}$

\begin{tabular}{|c|c|c|c|c|}
\hline & \multicolumn{2}{|c|}{ Peak $\dot{\mathrm{V}}_{\mathrm{O}_{2}}<16 \mathrm{~mL} / \mathrm{kg} / \mathrm{min}$} & \multicolumn{2}{|c|}{ Peak $\dot{\mathrm{V}}_{\mathrm{O}_{2}} \geq 16 \mathrm{~mL} / \mathrm{kg} / \mathrm{min}$} \\
\hline & $\begin{array}{c}\dot{\mathrm{VE}} / \dot{\mathrm{V}}_{\mathrm{CO}_{2}} \\
\text { Slope }\end{array}$ & $\begin{array}{l}\dot{\mathrm{V}}_{\mathrm{E}} / \dot{\mathrm{V}}_{\mathrm{CO}_{2}} \\
\text { Intercept }\end{array}$ & $\begin{array}{c}\dot{\mathrm{V}}_{\mathrm{E}} / \dot{\mathrm{V}}_{\mathrm{CO}_{2}} \\
\text { Slope }\end{array}$ & $\begin{array}{l}\dot{\mathrm{V}}_{\mathrm{E}} / \dot{\mathrm{V}}_{\mathrm{CO}_{2}} \\
\text { Intercept }\end{array}$ \\
\hline $\begin{array}{l}\text { Area under } \\
\text { the curve }\end{array}$ & 0.732 & 0.951 & 0.509 & 0.820 \\
\hline$P$ & .006 & .001 & .92 & .001 \\
\hline Cutoff point & 36.5 & $2.14 \mathrm{~L} / \mathrm{min}$ & & $2.72 \mathrm{~L} / \mathrm{min}$ \\
\hline Sensitivity & 0.62 & 0.92 & & 0.64 \\
\hline Specificity & 0.79 & 0.96 & & 0.96 \\
\hline
\end{tabular}

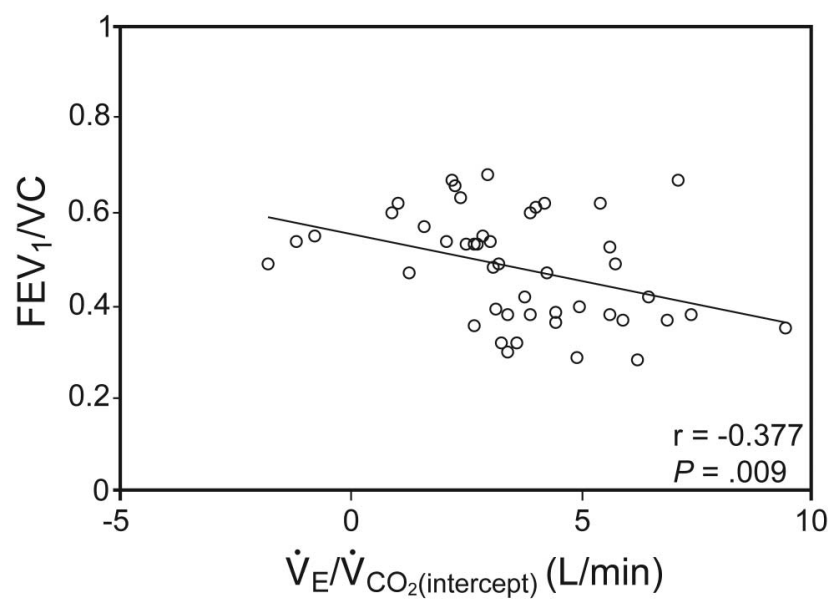

Fig. 2. Relationship between the minute ventilation $\left(\dot{V}_{E}\right)$ /carbon dioxide output $\left(\dot{\mathrm{V}}_{\mathrm{CO}_{2}}\right)$ intercept and $\mathrm{FEV}_{1} / \mathrm{NC}$ in 46 subjects with COPD.

when moderate-to-severe reduction in functional capacity was considered (see Table 1).

In all subjects with congestive heart failure and COPD, the $\dot{\mathrm{V}}_{\mathrm{E}} / \dot{\mathrm{V}}_{\mathrm{CO}_{2}}$ slope, but not the $\dot{\mathrm{V}}_{\mathrm{E}} / \dot{\mathrm{V}}_{\mathrm{CO}_{2}}$ intercept, was significantly related to peak $\dot{\mathrm{V}}_{\mathrm{O}_{2}}(\mathrm{r}=-0.59, P<.001$; $\mathrm{r}=-0.34, P=.02)$ and to peak work load $(\mathrm{r}=-0.46$, $P=.001 ; \mathrm{r}=-0.51, P=.001)$. The $\dot{\mathrm{V}}_{\mathrm{E}} / \dot{\mathrm{V}}_{\mathrm{CO}_{2}}$ intercept, but not the $\dot{\mathrm{V}}_{\mathrm{E}} / \dot{\mathrm{V}}_{\mathrm{CO}_{2}}$ slope, was significantly related to $\mathrm{FEV}_{1} / \mathrm{VC}$ in subjects with COPD $(\mathrm{r}=-0.38, P=.009)$ (Fig. 2).

\section{Discussion}

The main finding of the present study is that subjects with congestive heart failure are significantly different in ventilatory response to $\dot{\mathrm{V}}_{\mathrm{CO}_{2}}$ during exercise, as assessed by the $\dot{\mathrm{V}}_{\mathrm{E}} / \dot{\mathrm{V}}_{\mathrm{CO}_{2}}$ slope, compared with subjects with $\mathrm{COPD}$ at a moderate-to-severe (but not mild) reduction in exercise capacity. In contrast, they are significantly different in comparison with subjects with COPD regardless of the reduction in exercise capacity when the ventilatory response to $\mathrm{CO}_{2}$ during exercise is assessed by the $\dot{\mathrm{V}}_{\mathrm{E}} / \dot{\mathrm{V}}_{\mathrm{CO}_{2}}$ intercept. Our results also show that, according to receiver operating characteristic curve analysis when subjects with peak $\dot{\mathrm{V}}_{\mathrm{O}_{2}}<16 \mathrm{~mL} / \mathrm{kg} / \mathrm{min}$ are considered, subjects with COPD have a higher likelihood to have a $\dot{\mathrm{V}}_{\mathrm{E}} / \mathrm{V}_{\mathrm{CO}_{2}}$ intercept $>2.14 \mathrm{~L} / \mathrm{min}$ ( 0.92 sensitivity, 0.96 sensitivity). In addition, regardless of the degree of reduction in exercise capacity, peak $\mathrm{P}_{\mathrm{ETCO}}$ was not different in subjects with congestive heart failure, but was significantly higher in subjects with COPD compared with the corresponding unloaded $\mathrm{P}_{\mathrm{ETCO}_{2}}$. Finally, this study shows that the ventilatory response to $\dot{\mathrm{V}}_{\mathrm{CO}_{2}}$ is inversely related to resting lung function in subjects with COPD, when assessed by the $\dot{\mathrm{V}}_{\mathrm{E}} / \dot{\mathrm{V}}_{\mathrm{CO}_{2}}$ intercept, and to exercise capacity in both subjects with congestive heart failure and those with COPD, when assessed by the $\dot{\mathrm{V}}_{\mathrm{E}} / \dot{\mathrm{V}}_{\mathrm{CO}_{2}}$ slope.

An increase in the $\dot{\mathrm{V}}_{\mathrm{E}} / \dot{\mathrm{V}}_{\mathrm{CO}_{2}}$ slope may occur under several clinical conditions, including congestive heart failure, ${ }^{1,2,9}$ COPD, ${ }^{3,4}$ and pulmonary arterial hypertension. ${ }^{24}$ A previous study by Deboeck et $\mathrm{a}^{25}$ showed that at the same functional capacity, subjects with pulmonary arterial hypertension had significantly higher $\dot{\mathrm{V}}_{\mathrm{E}} / \dot{\mathrm{V}}_{\mathrm{CO}_{2}}$ slope values than subjects with congestive heart failure. Similarly, our study showed that, in the presence of a moderate-tosevere decrease in exercise tolerance, the $\dot{\mathrm{V}}_{\mathrm{E}} / \dot{\mathrm{V}}_{\mathrm{CO}_{2}}$ slope measurement may differentiate between congestive heart failure and COPD by finding the lowest values in subjects with COPD. It is of note that, taken together, the study by Deboeck et al ${ }^{25}$ and our study suggest that the ventilatory dysfunction, as assessed by the $\dot{\mathrm{V}}_{\mathrm{E}} / \dot{\mathrm{V}}_{\mathrm{CO}_{2}}$ slope, is minor in COPD compared with subjects with congestive heart failure or pulmonary arterial hypertension.

In the present study, we provided evidence that the $\dot{\mathrm{V}}_{\mathrm{E}} / \dot{\mathrm{V}}_{\mathrm{CO}_{2}}$ intercept measurement can discriminate between congestive heart failure and COPD regardless of the reduction in exercise capacity and that the $\dot{\mathrm{V}}_{\mathrm{E}} / \dot{\mathrm{V}}_{\mathrm{CO}_{2}}$ intercept was, on average, near zero in subjects with congestive heart failure and was positive in subjects with COPD. Notably, our data show that the mean $\dot{\mathrm{V}}_{\mathrm{E}} / \dot{\mathrm{V}}_{\mathrm{CO}_{2}}$ intercepts were 3.60 and $3.63 \mathrm{~L} / \mathrm{min}$ in subjects with COPD and -0.16 and $0.87 \mathrm{~L} / \mathrm{min}$ in subjects with congestive heart failure at peak $\dot{\mathrm{V}}_{\mathrm{O}_{2}}<16 \mathrm{~mL} / \mathrm{kg} / \mathrm{min}$ and peak $\dot{\mathrm{V}}_{\mathrm{O}_{2}}$ $\geq 16 \mathrm{~mL} / \mathrm{kg} / \mathrm{min}$, respectively. The positive intercept in the linear $\dot{\mathrm{V}}_{\mathrm{E}} / \dot{\mathrm{V}}_{\mathrm{CO}_{2}}$ relationship is considered by Whipp ${ }^{26}$ to be a dependent parameter that is secondary to a mechanistic coupling of $\dot{V}_{E}$ to changes in dead-space-to-tidalvolume ratio $\left(\mathrm{V}_{\mathrm{D}} / \mathrm{V}_{\mathrm{T}}\right)$ during exercise. According to Whipp's law, a significant intercept can result from a decrease in $\mathrm{V}_{\mathrm{D}} / \mathrm{V}_{\mathrm{T}}$ with increasing exercise $\dot{\mathrm{V}}_{\mathrm{E}}$ and, in this case, from an increasing mechanical constraint with in- 
creasing exercise $\dot{\mathrm{V}}_{\mathrm{E}}$ to conserve the work of breathing. ${ }^{7}$ It is of note that, in our subjects with COPD, the $\dot{\mathrm{V}}_{\mathrm{E}} / \dot{\mathrm{V}}_{\mathrm{CO}_{2}}$ intercept was inversely related to the corresponding $\mathrm{FEV}_{1} / \mathrm{VC}$.

In this study, peak $\mathrm{P}_{\mathrm{ETCO}_{2}}$, considered to be an estimateof $\mathrm{P}_{\mathrm{aCO}_{2}}{ }^{27}$ when compared with the corresponding unloaded $\mathrm{P}_{\mathrm{ETCO}}$ was significantly different in subjects with congestive heart failure compared with subjects with COPD regardless of the reduction in exercise capacity. These values were, on average, near zero in subjects with congestive heart failure and $7 \mathrm{~mm} \mathrm{Hg}$ in subjects with COPD. In patients with congestive heart failure, augmented hyperpnoea may occur and may reflect neural compensation for the increased pulmonary ventilation/perfusion mismatching during exercise, which increases the apparent metabolic $\mathrm{CO}_{2}$ load as perceived by the central respiratory controller. ${ }^{7}$ These patients may also experience exerciseinduced hyperventilation, which is due mainly to early onset of systemic lactic acidosis ${ }^{9}$ and/or to overactive reflexes from metaboreceptors, baroreceptors, and chemoreceptors, as part of a deranged cardiorespiratory reflex, ${ }^{28}$ although none of these reflexes have lasting effects on ventilatory control. ${ }^{7}$ In subjects with COPD, the increase in $\mathrm{V}_{\mathrm{D}} / \mathrm{V}_{\mathrm{T}}$ caused by gas exchange abnormalities resulting from deformed acini does not necessarily result in hypercapnia, which can occur, however, with excessive mechanical constraints. ${ }^{7}$

A limitation to our noninvasive study is the use of $\mathrm{P}_{\mathrm{ETCO}_{2}}$ as an estimate of $\mathrm{P}_{\mathrm{aCO}_{2}}$. $\mathrm{P}_{\mathrm{ETCO}_{2}}$ has the potential of underestimating $\mathrm{P}_{\mathrm{aCO}}$, in particular in patients with lung disease. ${ }^{27}$ Notably, our finding of a significantly lower resting $\mathrm{P}_{\mathrm{ETCO}_{2}}$ in subjects with COPD compared with subjects with congestive heart failure might be due to the fact that $\mathrm{P}_{\mathrm{ETCO}_{2}}$ could underestimate, to a greater extent, the corresponding $\mathrm{P}_{\mathrm{aCO}}$ in subjects with COPD. In addition, our finding of a significantly lower resting $\mathrm{P}_{\mathrm{ETCO}_{2}}$ in congestive heart failure subjects with lower peak $\dot{\mathrm{V}}_{\mathrm{O}_{2}}$ could be explained by the increase in $\mathrm{P}_{\mathrm{aCO}}-\mathrm{P}_{\mathrm{ETCO}_{2}}$ gradient due to an increase in $\mathrm{V}_{\mathrm{D}} / \mathrm{V}_{\mathrm{T}}$, as reported in congestive heart failure subjects ${ }^{29}$ and in animal models. ${ }^{30}$ Therefore, on the basis of our results, we can only infer, but not establish, the mechanisms underlying the ventilatory response to $\dot{\mathrm{V}}_{\mathrm{CO}_{2}}$ of subjects during exercise. Thus, an additional study with $\mathrm{P}_{\mathrm{aCO}_{2}}$ measurements is needed.

In summary, we have demonstrated that the ventilatory response to $\dot{\mathrm{V}}_{\mathrm{CO}_{2}}$ during progressive exercise is significantly different in subjects with congestive heart failure and those with COPD in terms of the slope of the $\dot{\mathrm{V}}_{\mathrm{E}} / \dot{\mathrm{V}}_{\mathrm{CO}_{2}}$ linear relationship with a moderate-to-severe reduction in exercise capacity, and in terms of the intercept of the $\dot{\mathrm{V}}_{\mathrm{E}} / \dot{\mathrm{V}}_{\mathrm{CO}_{2}}$ linear relationship, regardless of the exercise capacity. Notably, we found that the intercepts were positive in $93 \%$ of subjects with COPD and in $61 \%$ of subjects with congestive heart failure and that, in subjects with peak $\dot{\mathrm{V}}_{\mathrm{O}_{2}}<16 \mathrm{~mL} / \mathrm{kg} / \mathrm{min}$, a $\dot{\mathrm{V}}_{\mathrm{E}} / \dot{\mathrm{V}}_{\mathrm{CO}_{2}}$ intercept of 2.14 $\mathrm{L} / \mathrm{min}$ can highly discriminate between subjects with COPD and those with congestive heart failure.

\section{REFERENCES}

1. Buller NP, Poole-Wilson PA. Mechanism of the increased ventilatory response to exercise in patients with chronic heart failure. $\mathrm{Br}$ Heart J 1990;63(5):281-283.

2. Andreas S, Morguet AJ, Werner GS, Kreuzer H. Ventilatory response to exercise and carbon dioxide in patients with heart failure. Eur Heart J 1996;17(5):750-755.

3. Caviedes IR, Delgado I, Soto R. Ventilatory inefficiency as a limiting factor for exercise in patients with COPD. Respir Care 2012; 57(4):583-589.

4. Paoletti P, De Filippis F, Fraioli F, Cinquanta A, Valli G, Laveneziana $\mathrm{P}$, et al. Cardiopulmonary exercise testing (CPET) in pulmonary emphysema. Respir Physiol Neurobiol 2011;179(2-3):167-173.

5. Haouzi P. Theories on the nature of the coupling between ventilation and gas exchange during exercise. Respir Physiol Neurobiol 2006; 151(2-3):267-279.

6. Agostoni P, Apostolo A, Sciomer S. Evolution of the concept of ventilatory limitation during exercise. Combining the pneumologist and cardiologist point of view. Respir Physiol Neurobiol $2011 \mathrm{Dec}$ 15;179(2-3):127-128.

7. Poon CS, Tin C. Mechanism of augmented exercise hyperpnea in chronic heart failure and dead space loading. Respir Physiol Neurobiol 2013;186(1):114-130.

8. Wasserman K, Hansen JE, Sue DY. Normal values. In: Principles of exercise testing and interpretation. Philadelphia: Lippincott Williams \& Wilkins; 1994;143-162.

9. Sue DY. Excess ventilation during exercise and prognosis in chronic heart failure. Am J Respir Crit Care Med 2011;183(10):1302-1310.

10. Torchio R, Guglielmo M, Giardino R, Ardissone F, Ciacco C, Gulotta $\mathrm{C}$, et al. Exercise ventilatory inefficiency and mortality in patients with chronic obstructive pulmonary disease undergoing surgery for non-small-cell lung cancer. Eur J Cardiothorac Surg 2010; 38(1):14-19.

11. American Thoracic Society, American College of Chest Physicians. ATS/ACCP statement on cardiopulmonary exercise testing. Am J Respir Crit Care Med 2003;167(2):211-277.

12. Pauwels RA, Buist AS, Calverley PM, Jenkins CR, Hurd SS. GOLD Scientific Committee: global strategy for the diagnosis, management, and prevention of chronic obstructive pulmonary disease. NHLBI/WHO Global Initiative for Chronic Obstructive Lung Disease (GOLD) Workshop summary. Am J Respir Crit Care Med 2001;163(5):1256-1276.

13. Miller MR, Hankinson J, Brusasco V, Burgos F, Casaburi R, Coates A, et al. Standardisation of spirometry. Eur Respir J 2005;26(2):319-338.

14. Wanger J, Clausen JL, Coates A, Pedersen OF, Brusasco V, Burgos F, et al. Standardisation of the measurement of lung volumes. Eur Respir J 2005;26(3):511-522.

15. Quanjer PH, Tammeling GJ, Cotes JE, Pedersen OF, Peslin R, Yernault JC. Lung volumes and forced ventilatory flows. Report Working Party Standardization of Lung Function Tests, European Community for Steel and Coal. Official Statement of the European Respiratory Society. Eur Respir J Suppl 1993;16:5-40.

16. Le VV, Mitiku T, Sungar G, Myers J, Froelicher V. The blood pressure response to dynamic exercise testing: a systematic review. Prog Cardiovasc Dis 2008;51(2):135-160.

17. The Criteria Committee of the New York Heart Association. Nomenclature and criteria for diagnosis of diseases of the heart and great vessels, 9th edition. Boston: Little, Brown and Co; 1994:253-256. 
18. Brooks SM. Surveillance for respiratory hazards. ATS News 1982; 8:12-16.

19. Tzani P, Piepoli MF, Longo F, Aiello M, Serra W, Maurizio AR, Olivieri D, Chetta A. Resting lung function in the assessment of the exercise capacity in patients with chronic heart failure. Am J Med Sci 2010;339(3):210-215.

20. Sahn DJ, DeMaria A, Kisslo J, Weyman A. Recommendations regarding quantitation in M-mode echocardiography: results of a survey of echocardiographic measurements. Circulation 1978;58(6): 1072-1083.

21. Segal KR, Van Loan M, Fitzgerald PI, Hodgdon JA, Van Itallie TB. Lean body mass estimation by bioelectrical impedance analysis: a four-site cross-validation study. Am J Clin Nutr 1988;47(1):7-14.

22. Arena R, Sietsema KE. Cardiopulmonary exercise testing in the clinical evaluation of patients with heart and lung disease. Circulation 2011;123(6):668-680

23. Zweig MH, Campbell G. Receiver-operating characteristic (ROC) plots: a fundamental evaluation tool in clinical medicine. Clin Chem 1993;39(4):561-577.
24. Sun XG, Hansen JE, Oudiz RJ, Wasserman K. Exercise pathophysiology in patients with primary pulmonary hypertension. Circulation 2001;104(4):429-435.

25. Deboeck G, Niset G, Lamotte M, Vachiéry JL, Naeije R. Exercise testing in pulmonary arterial hypertension and in chronic heart failure. Eur Respir J 2004;23(5):747-751

26. Whipp BJ. Control of the exercise hyperpnea: the unanswered question. Adv Exp Med Biol 2008;605:16-21.

27. Stickland MK, Butcher SJ, Marciniuk DD, Bhutani M. Assessing exercise limitation using cardiopulmonary exercise testing. Pulm Med 2012;2012:824091.

28. Apostolo A, Giusti G, Gargiulo P, Bussotti M, Agostoni P. Lungs in heart failure. Pulm Med 2012;2012:952741.

29. Wasserman K, Zhang YY, Gitt A, Belardinelli R, Koike A, Lubarsky L, Agostoni PG. Lung function and exercise gas exchange in chronic heart failure. Circulation 1997;96(7):2221-2227.

30. Severinghaus JW, Stupfel M. Alveolar dead space as an index of distribution of blood flow in pulmonary capillaries. J Appl Physiol 1957;10(3):335-348

This article is approved for Continuing Respiratory Care Education credit. For information and to obtain your CRCE

(free to AARC members) visit 